operated on later. ${ }^{6}$ In the single centre in our series treating more than five cases a year the jaundice free survival rate with surgery before 8 weeks was $72 \%$ compared with $33 \%$ after 12 weeks. In this series three quarters of the infants were treated after 60 days of age and one third after 90 days.

These observations and the progressive nature of biliary atresia as evidenced by pathological studies ${ }^{17} 18$ suggest that if more infants are to benefit from treatment they must have surgery by 8 weeks of age. This will be possible only if suspected cases are identified earlier and referred to centres with the diagnostic skills to distinguish biliary atresia from the many intrahepatic causes of complete cholestasis, conditions for which surgery is contraindicated. ${ }^{19}$ Observations at King's College Hospital suggest that the major cause of delay in diagnosis is a failure to appreciate the importance of jaundice in infancy, particularly in a well grown, healthy looking baby. Parents should be advised that any jaundice persisting into the third week of life is unusual and requires referral to a paediatrician for investigation and possible treatment.

Family and community physicians, health visitors, and district nurses need reminding that persistently yellow or orange urine or stools with reduced pigment accompanying jaundice invariably indicates hepatobiliary disease, which in infants requires urgent investigation. Paediatric referral is often not initiated until review in the infant clinic at 6 weeks of age. If this examination was advanced to 4 weeks of age earlier treatment would be possible. At 4 weeks of age detection of other structural abnormalities and assessment of developmental or nutritional problems and of emotional difficulties in the childparent interaction-the main objectives of the examinationshould be no more difficult than at 6 weeks of age. In Japan infant review is at 1 month of age and the investigation of suspected biliary atresia has been concentrated in a few centres, in each of which the vast majority of operations are done by one surgeon. ${ }^{7}$ This survey suggests that a similar approach in the United Kingdom would increase the number of infants who become free of jaundice after surgery and may improve the long term prognosis in biliary atresia.
We are indebted to all members of the British Association of Paediatric Surgeons and the British Paediatric Association Gastroenterology Group for their encouragement and cooperation in pursuing this survey. We are grateful to Mrs Pamela Golding for typing the manuscript. Janet W McClement is supported by the Michael McGough Foundation Against Liver Disease in Children.

\section{References}

1 Mowat AP. Current developments in chronic liver disease. In: Hull D, ed. Recent advances in paediatrics. 6th ed. Edinburgh: Churchill Livingstone, $1981: 138-41$.

2 Adelman S. Prognosis of uncorrected biliary atresia: an update. $\mathcal{F}$ Pediatr Surg 1978;13:389-91.

3 Mowat AP, Psacharopoulos HT, Williams R. Extrahepatic biliary atresia versus neonatal hepatitis. A review of 136 prospectively investigated infants. Arch

Dis Child 1978;51:763-70.
4 Kasai M, Suzuki S. A new operation for "non-correctable" biliary atresia; hepatic portoenterostomy shait

Howard ER. Extrahepatic biliary atresia. In: Maingot $\mathbf{R}$, ed. Abdominal operations. 7th ed. New York: Appleton-Century-Crofts, 1980:1176-85.

6 Kasai $M$. Advances in treatment of biliary atresia. fpn $^{\prime} \mathcal{f}$ Surg 1983;13:265-76.

7 Hayes DM, Kimura K. Biliary atresia-the fapanese experience. Cambridge, Massachusetts: Harvard University Press, 1980.
M

8 Altman RP. Long-term results after the Kasai procedure. In: Daum F, ed. Extrahepatic biliary atresia. New York: Marcel Dekker Inc, 1983:91-8.

9 Jones PG, Danks DM, Smith A. Post-operative monitoring in biliary atresia. In: Kasai M, ed. Cholestasis in infancy. Tokyo: University of Tokyo Press, 1980:355-8.

10 Valayer J. Biliary atresia and portal hypertension. In: Daum F, ed. Extrahepatic

biliary atresia. New York: Marcel Dekker Inc, 1983:105-10.
Howard ER, Driver M, McClement J, Mowat AP. Results of surgery in 88 consecutive cases of extrahepatic biliary atresia. $R$ Soc Med 1982;75:408-13. Cholestasis in infancy. Tokyo: University of Tokyo Press, 1980:5-10. M, ed 13 Psacharopoulos HT, Mowat AP, Williams R. Epidemiological study of the hepatitis syndrome in England-incidence and early course. In: Kasai $M$, ed. Cholestasis in infancy. Tokyo: University of Tokyo Press, 1980:11-7.

14 Silverman A, Roy CC, Casetto FJ. Pediatric clinical gastroenterology. St Louis: C V Mosby Company, 1971:293-300.

15 Nyhan WL. Phenylketonuria. In: Rudolf AM, ed. Pediatrics. 17th ed. Norwalk, Connecticut: Appleton-Century-Crofts, 1982:258-60.

16 Hayes DM, Altman P, Hitch DC, Lilley JR, Smith EI, Urceda JE. Biliary atresia in the United States: the survey of the surgical section of the American Academy of Pediatrics. In: Kasai M, ed. Biliary atresia and its related disGautier. M, Elliot N. Extrahepatic biliary atresia: morphological study of 98 biliary remnants. Arch Pathol Lab Med 1981;105:379-404.

18 Lawrence D, Howard ER, Tsannotis C, Mowat AP. Hepatic portoenterostomy for biliary atresia; a comparative study of histology and prognosis after surgery. Arch Dis Child 1981;56:461-3.

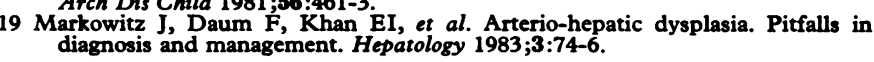

\title{
Use of anti-inflammatory drugs by patients admitted with small or large bowel perforations and haemorrhage
}

\author{
M J S LANGMAN, LINDA MORGAN, ANNE WORRALL
}

\begin{abstract}
The intake of anti-inflammatory drugs by 268 patients with colonic or small bowel perforation or haemorrhage was compared with that by a group of patients, matched for age and sex, with uncomplicated lower bowel disease. Patients with perforation or haemorrhage were more than twice as likely to be takers of anti-inflammatory drugs, but no association was detected with the intake of other types of drugs, particularly cardiovascular drugs.
\end{abstract}

Department of Therapeutics, University of Nottingham Medical School, Queen's Medical Centre, Nottingham NG7 2UH

M J S LANGMAN, MD, FRCP, professor

LINDA MORGAN, MB, CHB, research associate

ANNE WORRALL, MB, BS, research associate

Correspondence to: Professor M J S Langman.
The association between complicated lower bowel disease and intake of anti-inflammatory drugs may be causal.

\section{Introduction}

The causes of perforation of the gut below the duodenum, except perforation occurring in association with ischaemia, are poorly understood. Slow release enteric coated potassium supplements are known to cause solitary ulcers in the lower small intestine, ${ }^{1}$ and it has recently been suggested that the controlled release indomethacin preparation Osmosin may be particularly likely to cause perforation of the lower bowel. ${ }^{2}$ Whether other pharmaceutical preparations of non-steroidal anti-inflammatory drugs can damage the lower bowel wall is unknown, although anecdotal reports suggest that they may,,$^{3-5}$ and no general search has been made to determine if the use of potassium supplements in general or of other cardiovascular drugs is associated with intestinal damage. We therefore examined the drug histories of patients admitted to hospital 
with large bowel disease other than cancer, ulcerative colitis, or Crohn's disease to determine whether perforation and haemorrhage were associated with intake of anti-inflammatory or cardiovascular drugs.

\section{Patients and methods}

Searches were made for the case notes of patients aged 40 or over admitted to the Nottingham hospitals who at discharge or death in 1978-82 had records coded under a set of International Classification of Disease (ICD) numbers covering the likely diagnostic groups. These included numbers for non-infective enteritis and colitis (other than regional enteritis and idiopathic proctocolitis), vascular insufficiency, diverticular disease, peritonitis of unspecified cause, abscess, and other unspecified disorders of the intestine as small intestinal perforation below the duodenum and large intestinal perforation and bleeding are not coded, like peptic ulcer, under a single set heading. Table I shows the ICD codes examined. The records were then examined and information extracted about the disease necessitating admission and about the drugs taken by patients before admission as recorded by admitting staff. When drug histories were specified all individually recorded items were noted by us; in addition, we noted separately those records in which admitting staff had recorded that no drugs were being taken and those giving no indication of whether specific inquiries had been made.

A diagnosis of perforation of the small or large bowel was accepted if there was operative or necropsy evidence of perforation distal to the duodenojejunal flexure. Intestinal haemorrhage was accepted as a diagnosis if the patient had suffered from melaena, usually containing fresh blood, for which on clinical grounds an upper gastrointestinal source seemed unlikely and investigation had shown none.

Data obtained on patients with haemorrhage or perforation were compared with those on a group of patients admitted with uncomplicated bowel disease. These controls were matched for age and sex with the patients with complicated disease but were otherwise drawn randomly from the set of records obtained for patients with uncomplicated disease. Results were analysed by the method of Miettinen.?

\section{Results}

Altogether 740 sets of records were extracted using 13 separate ICD codes; table I shows the proportions of patients who were definitely recorded as taking or not taking drugs when admitted, the proportion for whom no drug history was recorded, the average number of items recorded per drug taker, and the proportion in each diagnostic category with complicated disease. Just over two thirds of all patients (506 out of 740) were noted to be taking drugs; just over a fifth (165) were recorded not to be taking drugs; and in rather under a tenth (69) no drug history was recorded. Neither the proportions of drug takers nor the average number of drugs per taker varied significantly by diagnostic category.

Table II similarly compares the proportions of patients taking and not taking drugs and the average number of drugs taken for patients
TABLE II-Drug histories taken on admission in 740 patients with and without complicated bowel disease

\begin{tabular}{|c|c|c|c|c|c|}
\hline \multirow[b]{2}{*}{ Patient category } & \multirow[b]{2}{*}{$\mathbf{n}$} & \multicolumn{3}{|c|}{ No $(\%)$ of patients } & \multirow[b]{2}{*}{$\begin{array}{c}\text { Average No } \\
\text { of items } \\
\text { per patient }\end{array}$} \\
\hline & & $\begin{array}{c}\text { Definitely } \\
\text { taking } \\
\text { drugs }\end{array}$ & $\begin{array}{l}\text { Definitely } \\
\text { not taking } \\
\text { drugs }\end{array}$ & $\begin{array}{l}\text { With uncertain } \\
\text { drug } \\
\text { history }\end{array}$ & \\
\hline $\begin{array}{l}\text { Perforation: } \\
\text { Small intestine } \\
\text { Large intestine } \\
\text { Haemorrhage }\end{array}$ & $\begin{array}{r}25 \\
82 \\
161\end{array}$ & $\begin{array}{r}14(56) \\
56(68) \\
114(71)\end{array}$ & $\begin{array}{r}7(28) \\
16(20) \\
37(23)\end{array}$ & $\begin{array}{r}4(16) \\
10(12) \\
10(6)\end{array}$ & $\begin{array}{l}2 \cdot 2 \\
2 \cdot 2 \\
2 \cdot 2\end{array}$ \\
\hline Total & 268 & $185(69)$ & $59(22)$ & $24(9)$ & $2 \cdot 2$ \\
\hline All other groups & 472 & $321(68)$ & $109(23)$ & $42(9)$ & 2.5 \\
\hline
\end{tabular}

with perforation or haemorrhage of lower intestinal origin and for the remainder without such complications. The proportions of patients definitely taking and not taking drugs in the overall groups with and without complications did not differ materially, and the average number of items per taker was slightly greater among those with uncomplicated disease. The smaller proportion of takers among those with small bowel perforation compared with the remainder could well have arisen by chance.

Table III shows the proportions of patients with small or large

TABLE III-Recorded intake of anti-inflammatory drugs by patients with and without complicated bowel disease

\begin{tabular}{|c|c|c|c|c|}
\hline & $\begin{array}{l}\text { Patients with } \\
\text { small or } \\
\text { large bowel } \\
\text { perforation } \\
(\mathbf{n}=107)\end{array}$ & $\begin{array}{c}\text { Age } \\
\text { and sex } \\
\text { matched } \\
\text { controls } \\
(\mathbf{n = 1 0 7 )}\end{array}$ & $\begin{array}{l}\text { Patients with } \\
\text { small or } \\
\text { large bowel } \\
\text { haemorrhage } \\
(\mathbf{n}=161)\end{array}$ & $\begin{array}{c}\text { Age } \\
\text { and sex } \\
\text { matched } \\
\text { controls } \\
(\mathbf{n}=161)\end{array}$ \\
\hline $\begin{array}{l}\text { No of patients taking: } \\
\text { Non-steroidal anti- } \\
\text { inflammatory drugs alone } \\
\text { Corticosteroids alone } \\
\text { Non-steroidal anti- } \\
\text { inflammatory drugs and } \\
\text { corticosteroids }\end{array}$ & $\begin{array}{r}17 \\
4 \\
7\end{array}$ & $\begin{array}{r}10 \\
2\end{array}$ & $\begin{array}{r}29 \\
4\end{array}$ & $\begin{array}{r}10 \\
6\end{array}$ \\
\hline Total No $(\%)$ of takers & $28(26 \cdot 2)$ & $13(12 \cdot 1)$ & $36(22 \cdot 4)$ & $16(10)$ \\
\hline $\begin{array}{l}\text { Patients with perforation } v \\
\text { controls } \dagger \\
\text { Patients with haemorrhage } v \\
\text { controls } \dagger\end{array}$ & Relative risk & $\begin{array}{l}5.91 \\
8.28\end{array}$ & \multicolumn{2}{|c|}{$\begin{array}{l}4 \cdot 13-1 \cdot 62 \\
4 \cdot 85-1 \cdot 40\end{array}$} \\
\hline $\begin{array}{l}\text { Particular drugs*: } \\
\text { Azapropazone } \\
\text { Benoxaprofen } \\
\text { Diflunisal } \\
\text { Fenoprofen } \\
\text { Flurbiprofen } \\
\text { Ibuprofen } \\
\text { Indomethacin } \\
\text { Ketoprofen } \\
\text { Mefanamic acid } \\
\text { Naproxen } \\
\text { Phenylbutazone } \\
\text { Piroxicam } \\
\text { All varieties of aspirin }\end{array}$ & $\begin{array}{l}2 \\
3 \\
7 \\
4\end{array}$ & $\begin{array}{l}1 \\
3 \\
4 \\
1\end{array}$ & $\begin{array}{l}1 \\
1 \\
1 \\
2 \\
7 \\
7 \\
1 \\
1 \\
4 \\
3 \\
1 \\
5\end{array}$ & $\begin{array}{l}2 \\
1 \\
1 \\
3 \\
1 \\
1 \\
1\end{array}$ \\
\hline
\end{tabular}

Corticosteroids not included. Numbers greater than numbers of patients because

some patients were taking more than one drug.

TABLE I-Details of patients with lower bowel disease according to general diagnostic categories

\begin{tabular}{|c|c|c|c|c|c|c|c|c|}
\hline \multicolumn{2}{|r|}{ Diagnosis } & \multirow{2}{*}{$\mathbf{n}$} & \multicolumn{3}{|c|}{ Drug history } & \multirow{2}{*}{$\begin{array}{l}\text { Average No } \\
\text { of items } \\
\text { per taker }\end{array}$} & \multicolumn{2}{|c|}{ No $(\%)$ of patients with: } \\
\hline ICD code & Description & & No $(\%)$ of takers & No $(\%)$ of non-takers & No (\%) uncertain & & Perforation & Bleeding \\
\hline 556.9 & Idiopathic proctocolitis of unspecified type & 5 & $2(40)$ & $3(60)$ & $\mathbf{0}$ & $2 \cdot 0$ & $1(20)$ & $3(60)$ \\
\hline $\left.\begin{array}{l}557.0 \\
557.1 \\
557.9\end{array}\right\}$ & $\begin{array}{l}\text { Vascular insufficiency of the intestine, } \\
\text { acute, chronic, and unspecified }\end{array}$ & 76 & $54(71)$ & $12(16)$ & $10(13)$ & 2.5 & $7(9)$ & $14(18)$ \\
\hline 558.9 & $\begin{array}{l}\text { Other non-infective gastroenteritis and } \\
\text { colitis of unspecified type }\end{array}$ & 87 & $59(68)$ & $23(26)$ & $5(6)$ & $2 \cdot 4$ & $3(3)$ & $10(11)$ \\
\hline 562.0 & Small intestinal diverticulosis & 18 & $12(006)$ & $3(17)$ & $3(17)$ & $2 \cdot 3$ & $8(4)$ & $\mathbf{0}$ \\
\hline 562.1 & Colonic diverticulosis & 469 & $319(68)$ & $108(23)$ & $42(9)$ & $2 \cdot 3$ & 53 (11) & $121(26)$ \\
\hline $\left.\begin{array}{l}567.2 \\
567.9\end{array}\right\}$ & $\begin{array}{l}\text { Other suppurative peritonitis and peritonitis } \\
\text { of unspecified type }\end{array}$ & 28 & $17(61)$ & $6(21)$ & $5(18)$ & $2 \cdot 4$ & $15(54)$ & 1 (4) \\
\hline $\left.\begin{array}{l}569.4 \\
569.5 \\
569.8 \\
569.9\end{array}\right\}$ & $\begin{array}{l}\text { Other disorders of rectum and anus, } \\
\text { abscess of intestine, other disorders } \\
\text { of the intestine, and other unspecified } \\
\text { disorders }\end{array}$ & 57 & $43(75)$ & $9(16)$ & $5(9)$ & $2 \cdot 3$ & $20(35)$ & $12(21)$ \\
\hline Total & & 740 & $506(68 \cdot 4)$ & $165(22 \cdot 3)$ & $69(9 \cdot 3)$ & $2 \cdot 4$ & $107(14)$ & $161(21)$ \\
\hline
\end{tabular}


intestinal perforation and with lower bowel haemorrhage who were noted to be taking anti-inflammatory drugs together with details of particular drugs being taken. It also shows the same information for a sample of patients, matched for age and sex, with uncomplicated lower bowel disease.

Anti-inflammatory drugs of any type were being taken at the time of their admission by over a quarter $(28(26 \%))$ of patients with small or large bowel perforation but by only $13(12 \%)$ of their matched controls. Such drugs were also being taken by over a fifth $(36(22 \%))$ of patients with lower bowel haemorrhage but by only $16(9.5 \%)$ of their matched controls. Both differences were highly significant $\left(\chi^{2}=5.91\right.$ and $\chi^{2}=8.28$, respectively; $p<0.01$ in both cases).

Patients with complicated disease of either type were more likely to be taking ibuprofen, indomethacin, naproxen, phenylbutazone, diflunisal, aspirin, or corticosteroids together with non-steroidal anti-inflammatory agents than their matched controls but were no more likely to be taking flurbiprofen or corticosteroid drugs alone. All differences were small, however, and could well have arisen by chance. The controlled release indomethacin preparation Osmosin was not recorded on any occasion.

Table IV shows patterns of intake of cardiovascular drugs for patients with complicated bowel disease and their matched controls. No consistent and significant differences were detectable between patients and controls. Diuretics containing potassium, and potassium supplements, were taken slightly more often by patients with perforated disease and potassium sparing diuretics slightly less often than by their controls, but the difference was small, non-significant, and unmatched by any parallel trend for patients with bowel haemorrhage.

TABLE IV-Recorded intake of cardiovascular drugs by patients with and without complicated bowel disease

\begin{tabular}{lcccc}
\hline & $\begin{array}{c}\text { Patients with } \\
\text { small or } \\
\text { large bowel } \\
\text { perforation } \\
(\mathrm{n}=107)\end{array}$ & $\begin{array}{c}\text { Age } \\
\text { and sex } \\
\text { matched } \\
\text { controls } \\
(\mathrm{n}=107)\end{array}$ & $\begin{array}{c}\text { Patients with } \\
\text { small or } \\
\text { large bowel } \\
\text { perforation } \\
(\mathrm{n}=161)\end{array}$ & $\begin{array}{c}\text { Age } \\
\text { and sex } \\
\text { matched } \\
\text { controls } \\
(\mathrm{n}=161)\end{array}$ \\
\hline $\begin{array}{l}\text { Separate potassium } \\
\text { supplements }\end{array}$ & 3 & 5 & 8 & 3 \\
$\begin{array}{l}\text { Thiazide or loop diuretics } \\
\text { combined with potassium }\end{array}$ & 11 & 7 & 7 & 12 \\
$\begin{array}{l}\text { All other cardiovascular drugs } \\
\text { Average No of drugs per } \\
\text { patient }\end{array}$ & 44 & 35 & 62 & 81 \\
\hline & Relative risk & $x^{2}$ & $95 \%$ confidence limits \\
\hline $\begin{array}{l}\text { Patients with perforation } v \\
\text { controls* }\end{array}$ & 1.19 & 0.04 & $2.71-0.52$ & 0.6 \\
$\begin{array}{l}\text { Patients with haemorrhage } v \\
\text { controls* }\end{array}$ & 1.00 & 0.04 & $2.09-0.77$ & \\
\hline
\end{tabular}

*Difference in numbers taking drugs containing potassium.

\section{Discussion}

Perforation and haemorrhage are occasional and well described complications of idiopathic ulcerative colitis and Crohn's disease, and perforation may occur in established bowel infarction. In general, however, the incidence of such events is not clear. Although a sample of one tenth of all hospital discharges and deaths is routinely extracted and enumerated, perforation and bleeding of non-peptic origin are not classified under a single unified code. We searched extensively through a series of ICD codes but cannot be sure that the 107 cases of perforation and 161 cases of bleeding found were all those admitted in the five years reviewed. The Nottingham hospitals take patients from a surrounding population of some 800000 , of whom about $40 \%$ would be aged 40 or over; minimum crude incidences would therefore be of the order of seven perforations and 10 haemorrhages per 100000 population. These estimates can be placed in context by comparing them with figures for the incidence of perforated duodenal ulcer in the United Kingdom. These vary from 22 to 46 per 100000 in men and from six to 17 per 100000 in women aged from 45 to $75 .^{6}$

Ulceration of the lower small bowel has been ascribed to the use of enteric coated potassium supplements, and more recently it has been suggested that the slow release indomethacin preparation Osmosin, by releasing drug at high concentrations at a specific site, causes lower bowel perforation in patients without mucosal disease. Anecdotal case reports such as these are difficult to evaluate. We could find no previous case-control studies comparing the drug intake of patients with bleeding or perforation with the intake of patients without these complications, probably because lower bowel perforation and bleeding have been thought to be so rare that planned retrospective studies in which patients are deliberately questioned about their drug intake before admission would be impracticable. We have had to depend on drug histories obtained by admitting house staff and have compared these in patients with complicated and uncomplicated lower bowel disease. Findings could clearly be affected if the intensity of questioning varied from one group of patients to another. Our data suggest that this was unlikely to have occurred. Thus table III shows that proportions of case histories that did not include any mention of inquiries about antecedent drug intake did not differ materially between patients with bleeding or perforation and those without. Furthermore, the average number of items recorded per taker was, if anything, lower in those with complicated rather than uncomplicated disease. By contrast, intake of anti-inflammatory drugs was recorded twice as often in patients with bleeding or perforation as in their matched controls.

As the intake of anti-inflammatory drugs is widely believed to cause peptic ulcer complications our patients with complicated lower bowel disease may have been questioned particularly intensively about their intake of such drugs. We think, however, that this is unlikely. Firstly, we found no material difference in the intake of potassium containing agents in particular, or cardiovascular drugs in general, by patients with complicated bowel disease, although an association with potassium intake had previously been reported; if more intensive questioning had occurred items containing potassium might have been noted more often in case histories of patients with complicated disease. Secondly, the recorded intake of anti-inflammatory drugs by controls was, at $10 \%$, of the same order as the intake recorded during a planned retrospective study in which a random sample of patients aged over 60 from Nottingham general practitioners' lists were questioned about the use of antiinflammatory drugs (Langman, unpublished data).

We suggest that patients with bowel perforation or haemorrhage are particularly likely to be takers of anti-inflammatory drugs and that the association may be causal. In earlier studies we found that the relative risk of developing upper gastrointestinal bleeding is roughly doubled in patients taking aspirin. ${ }^{8}$ If the figures that we have presented here are correct the relative risks associating the intake of anti-inflammatory drugs with bowel perforation and haemorrhage may be slightly greater.

We thank Merck Sharp and Dohme for financial support and our colleagues for permission to examine case records.

\section{References}

1 Davies DR, Brightmore T. Idiopathic and drug-induced ulceration of the small

2 intestine. Br $\mathcal{F}$ Surg $1970 ; 57: 134-9$. capsules. Br Med f 1983;287:1671-2.

Lower gastrointestinal side effects of non-steroidal antiinflammatory drugs. $₹$ Rheumatol $1981 ; 8: 952-4$

4 Controi S, Roland D, Barbier J, van der Marca P, Alcalay M, Matuchansky C. Acute perforation of colonic diverticula associated with short-term indomethacin. Lancet 1978; ii:1055-6.

5 Sturges HF, Krone CL. Ulceration and stricture of the jejunum in a patient on long-term indomethacin therapy. Am $\mathcal{F}$ Gastroenterol 1973;59:162-9.

6 World Health Organisation. International classification of diseases. Manual of the international statistical classification of diseases, injuries and causes of death. Geneva: WHO, 1977

7 Miettinen OS. Estimability and estimation in case-referrent studies. Am $\mathcal{J}$ Epidemiol 1976;103:226-35.

temesis and melaena. Mut Spiegelhalter D. Aspirin, paracetamol and haema-

(Accepted 30 October 1984) 